\title{
Journal of Language and Linguistic Studies
}

Vol.2, No.2, October 2006

\section{Research in the Language Classroom: State of the Art}

\author{
Mohammad Ali SALMANI-NODOUSHAN \\ nodushan@ut.ac.ir
}

\begin{abstract}
New trends in language teaching have resulted in a move towards research in the language classroom. A brief overview of classroom research reveals three distinct but interrelated research paradigms: classroom-centered research, classroom process research, and qualitative research, respectively.
\end{abstract}

Key words: Classroom-Centered Research; Classroom-Process Research; Qualitative Research; Research in the language classroom; Quality research

\section{Introduction}

This paper is an attempt at providing a brief but thorough account of research in the language classroom. The paper will begin with an overview of Classroom-Centered Research (CCR) and will, then, go on to an evaluation of Classroom-Process Research (CPR). It will then shed light on the place of Qualitative Research $(\mathrm{QR})$ in connection to language classroom contexts, and will finally introduce the more recent notion of Quality Research (QLR) and its application to the language classroom.

\section{Classroom-Centered Research}

By definition, classroom-centered research is simply research centered on the classroom as distinct from other research types. This research type usually views classroom as the "object" of research, and not simply the "setting" for research. Classroom-centered research should, however, be taken as a cover term for a whole range of research studies on classroom language learning. 
Research on classroom language learning is basically done by either observation or introspection, or even a combination of both. Observation necessarily implies keeping a record of what goes on in the classroom. To this end, different techniques are available to the researcher. The use of audio-tape recordings, video-tape recordings, and so on could be enlisted as some of these techniques. Even a trained observer can handle the job of doing the observation.

A second approach to classroom-centered research is introspection. Allwright (1988) uses the term 'introspection' to refer to research techniques that involve, for instance, asking people to answer questions rather than asking them to allow themselves to be observed in action. In any case, introspection always calls for self-reporting of some kind. The use of questionnaires or interviews can be viewed as a good means of eliciting introspective data; a fairly recent development is the use of diary keeping.

A third approach is the use of what can safely be called "triangulation." Multiple viewpoints, at least three, may be necessary if we are to understand what actually goes on in classrooms. Allwright (1988) argues that, in practice, triangulation means a combination of observation and introspection. This calls for a good number of observers and introspects.

Modern classroom-centered research is deeply rooted in the attempts of teacher trainers (in the fifties) at responding to the need to provide student teachers with adequate feedback on their teaching. At that time, the finding out of what constituted good effective teaching was of prime importance. Teacher trainers believed that only through such investigations would it be possible to train effective teachers. To this end, it was necessary to develop the tools of classroom observation. Some scholars as Flanders (1960) chose to use direct observation. Some others developed what they called observation schedules. Early on, the researchers realized that the application of their findings to teacher development was actually premature. This finding shed light on Dunkin and Biddle's (1974) claim that the enormous complexity of classroom behavior is so varied that it could never be simply reduced to a few categories.

Classroom-centered research is a somewhat new trend in the field of language teaching profession. One reason why the language teaching profession realized the importance of this research type so late might be the fact that language teachers have been enjoying a period of euphoria and unprecedented confidence in the methods they used in their classrooms. This preoccupation with methods could be eloquently called the era of global methodological 
prescription (Allwright, 1988). That is, instead of realizing what actually happened in the classroom, the training of language teachers was informed by the issue of which of the major methods to prescribe. It was not until very late in the 1960s that the scholars in this profession began to realize, in the light of research done by Scherer and Wertheimer (1964), Smith (1970), and others that it no longer made sense to imagine that any one method would prove in some absolute way superior to its rivals.

This urged some scholars to move a step down the hierarchy of approach-methodtechnique (see, Richards and Rodgers, 2001). They, therefore, began to carry out the so-called small-scale research projects at the level of technique. In Sweden, for instance, the Gothenburg English Teaching Method (GUME) Project was an offspring of such an orientation toward technique and away from method. In the US, Politzer (1970) video-taped a number of language classes, recorded the frequencies with which certain techniques (e.g., structural pattern practice) were used, and correlated these frequencies with learner achievements in different classes. Politzer (1970, p. 42) notes that "the very high complexity of the teaching process makes it very difficult to talk about bad and good teaching devices in absolute terms."

It was soon apparent that the level of technique was not a reliable place to dwell in. Therefore, it seemed inevitable to retreat even a further step back into the kept-in-the-dark arena of classroom processes. That is, two moves were involved in classroom-centered research: (1) movement from prescription to description; and (2) movement from technique to classroom processes. These two moves, when taken together, called for an effort to find ways of describing classroom processes to find out what actually happened in language classes.

As such, classroom-centered research has been divided into two distinct branches. On the one hand, some scholars have drawn on a sociological outlook on education and have tended to look at language lessons as socially constructed events. The teacher in this approach is no longer viewed as the all-knower and the only available source of knowledge. Classroom activity is viewed as a collective endeavor toward the production of learning opportunities. On the other hand, some other scholars including Gaies (1977) have viewed the language classroom as a setting for Classroom Language Acquisition. The teacher in this approach is viewed as a source of input. The role of teacher talk in classroom language acquisition is the main focus of 
investigation. These two approaches should, however, be viewed as complementary rather than mutually exclusive practices.

The twin moves from (a) prescription to description and (b) technique to process have resulted in a move from teacher training to something more like fundamental research. This, no doubt, has resulted in a revision of the tools of classroom-centered research. Observation schedules have been modified so that they will be appropriate to the obvious complexities of language teaching. Moskowitz (1971) produced the most widely known and used modification of a general educational schedule and called it Foreign Language Interaction System (FLINT). FLINT was actually the expanded form of Flanders's (1960) sign system known as FIAC (see Richards and Nunan, 1990). FLINT was used as a research tool in deciding what constituted effective teaching. Fanselow (1977), in an important contribution to this area, produced an observation schedule which was called Foci for Observing Communication Used in Settings (FOCUS). The FOCUS was primarily developed with language teacher training in mind. It is, however, a good descriptive system applicable to almost any human interaction (see Gebhard, Gaitan, and Oprandy, 1990).

In brief, classroom-centered research should be viewed in the light of three important issues. First, the two viewpoints (i.e. focusing on the interactive aspects of classroom behavior, and focusing on the process of classroom language acquisition) should be taken together as being complementary. Second, the study of classroom language acquisition as opposed to natural language acquisition is still in its infancy period. And, third, there is a controversy over what constitutes the appropriate research methods for classroom-centered research. That is, some researchers prefer objectivism while others accept subjective methods as valid (cf., Allwright, 1983; Allwright and Bailey, 1991; Bailey, 1982; Bailey, 1985; Bailey, 1990; Bartlett, 1990; Blum, 1984; Cohen, 1990; Moskowitz, 1967; Porter, et al., 1990).

\section{Classroom-Process Research}

Gaies (1983a) drew on a new dimension on classroom-centered research which is often called Classroom Process Research (CPR). According to Gaies, besides the ethonomethodological trend in sociolinguistics which set out to investigate the kind of interaction that went on in language classrooms, a second dimension of research concerns itself 
with the investigation of classroom processes. It gives priority to the direct observation of second language classroom activity. Classroom-process research is primarily concerned with the investigation of the numerous factors that shape language acquisition in language classes. Classroom-process research aims at describing the linguistic and instructional environment which second language learners encounter in the classroom and how that environment might differ from what is available outside the classroom.

It is commonly believed that classroom-process research is based on several shared premises. It is vital to summarize these premises at the outset:

A. There has been, as Allwright (1988) argues, a perceptible trend away from global categorization of second language classroom instruction. In fact, classroom-process research rejects any univariate classification of second language instruction as simplistic.

B. The emphasis is on describing as fully as possible the complexity of second language instructional environment. Classroom-process research tries to identify the variables that shape classroom language instruction. In so doing, it generates hypotheses. Therefore, classroom-process research is considered to be hypothesis generating. It does not directly lead to empirically validated applications; rather, it is directed more at the clarification of those factors which must be taken into account in any given assessment of what goes on in language classrooms.

C. The priority of direct observation of classroom activity is another premise which unifies classroom-process research. The main source of data in this research type is wholly or substantially the classroom itself. Teacher talk functions as the major source of input which informs learners' language acquisition.

D. The major trends in classroom-process research include 'second language classroom' language (classroom input), error treatment, and patterns of classroom participation.

Perhaps one of the most interesting aspects of classroom process research is the investigation of the nature of classroom input. According to Gaies (1983b), the language classroom provides what might be almost totally inaccessible outside the class--a native speaker (or a really proficient non-native speaker) who is delegated to interact with learners and to 
provide them with linguistic input. Gaies (1977), in an investigation of the syntactic features of ESL classroom teachers, revealed that the subjects' classroom speech was syntactically less complex on a number of variables. The subjects of this investigation were observed to drastically fine-tune their classroom speech to the level of their learners' proficiency.

Hamayan and Tucker (1980) carried out another investigation in two French immersion schools and three regular French schools in Montreal. The subjects of their study were teachers of the third and fifth grade level classes. They examined the speech and teaching behavior of these subjects. The linguistic aspects of the speech they studied included indirect questions, contractions, reflexives, and subjunctive (usually viewed as the most complex syntactic aspects of any language). They found strong correlation in the frequency with which these structures occurred at the two grade levels and in the two school systems. They also found that the frequency with which students used these structures in story retelling tasks correlated strongly with the frequency of occurrence of these structures in the speech of their teachers. This reveals the old claim that classroom linguistic input shapes learners' linguistic production.

More recently, another important aspect of classroom-process research has come into vogue. Attention has shifted from the nature of input to the nature of interaction between native speakers and second language acquirers. A prominent figure in this connection is Krashen (1978, 1980) who argues that, through interaction, second language acquirers gain access to what he calls optimal input (i.e., input which is likely to lead to further acquisition). Long (1980b) claims that the modified input available to second language acquirers through interaction between native speakers (here, the teacher) and the learners is the necessary and sufficient condition for second language acquisition to take place.

Long and Sato (1983) examined the forms and functions of ESL teachers' classroom questions. They hypothesized that questions in and outside the classroom tend to serve different interactional functions. They classified questions as belonging to either the 'display type' category (i.e., questions which are intended to elicit information already known to the questioner) or the 'referential type' category (i.e., questions intended to provide referential or expressive information unknown to the teacher). The most striking point in their findings was the observation of the total absence of display type question in data gathered in naturalistic settings outside the classroom. 
Roughly at the time when language classroom process research began on a large scale, interaction analysis predominated in educational research. A good example of such interaction analyses is the study carried out by Flanders (1970) (section 2 above). Seliger (1977) in another study classified learners into the two categories of 'high input generators' and 'low input generators' on the basis of a numerical count of classroom participation. The findings of this study showed that 'high input generators' (i.e., the students who were more active in classroom interaction) tended to be more field independent in their cognitive styles.

Sato (1981) studied the patterns of turn-taking in university-level ESL classes. This study is an excellent illustration of how classroom-process research may serve to refine our understanding of patterns of participation. She compared nineteen Asian and twelve non-Asian learners and found that Asian learners initiated significantly fewer turns than did their non-Asian counterparts. In addition, the Asian students were less often called upon by their teachers.

Schinke (1981) has examined patterns of participation in all-English content classes. She examined the experience of Limited English Proficiency (LEP) learners who had been mainstreamed. She found that LEP learners had significantly fewer interactions with their teachers than their non-LEP classmates. Teacher-LEP interaction was also revealed to be functionally quite different from the type of interaction in which non-LEP learners and the teacher engaged. The LEP-teacher interaction was mainly concerned with classroom and lesson management.

A third dimension in classroom-process research is the investigation of error treatment patterns in language classrooms. This research type is mainly concerned with the investigation of the role of corrective feedback in classroom language acquisition. Errors have been viewed as windows to the nature of language acquisition process. They are seen as overt reflections of learners' internalized knowledge of the language. One major step forward in this connection is the abandonment of a 'global' or all-out approach to error correction in the classroom. Fanselow (1977), for instance, found that $22 \%$ of the errors committed by students received no treatment of any sort.

A second trend in research on error treatment has focused on the nature of corrective feedback. In other words, researchers have sought to study the type of error treatment which is provided by teachers. An important finding in this connection is that when teachers treat errors in 
the second language classroom, they do not necessarily provide overt corrections. They rather prefer to provide implicit or indirect feedback. In a study by Catheart and Olsen (1976), twentyone teachers of adult and university ESL classes responded to a questionnaire which asked for their preferred and most frequently used error treatment strategies. The students in these teachers' classes were also asked to respond to the same questionnaire. The only striking discrepancy between the teachers' preferences and those of their students was the students' wish to be corrected much more frequently than their teachers actually did.

On the whole, studies concerning error treatment revealed that the type of corrective feedback provided by teachers depends on a number of factors. The first of these factors concerns the type of linguistic error committed by the learners. Studies on error treatment reveal that, based on their linguistic type (i.e., their phonological, lexical, syntactic nature), errors are treated differently. The type of classroom activity during which an error occurs is yet another factor that plays a major role in the treatment of errors. As mentioned earlier in the discussion of the study carried out by Hayaman and Tucker (1980), the level of instruction also plays a major role in the type of corrective feedback provided by the teacher. Finally, the teachers' individual styles are also significant determinants of error treatment.

The studies reviewed up to here, on the whole, reveal that error treatment in language classrooms is often inconsistent and ambiguous. Chaudron (1977), for instance, has pointed out that error treatment usually consists of not a single teacher response, but rather of an exchange or cycle of verbal moves. Feedback has also been categorized into two types: (1) negative cognitive feedback (i.e., feedback that focuses attention on an error), and (2) positive affective channel feedback (i.e., feedback that encourages the learners to make further attempts at communication).

There are alternative approaches to classroom-process research. These alternative approaches are known by a variety of headings, among which are anthropological, qualitative, and mentalistic research. According to Cohen and Hosenfield (1981), the chief virtue of classroom-process research is that it allows for the investigation of aspects of classroom language learning which escape the attention of more conventional external investigation methods. In fact, a comparison of conventional and non-conventional methods of classroomprocess research reveals that: 
A. Conventional classroom observation provides insufficient accounting of learners who are reluctant to participate orally in class.

B. Direct external observation cannot provide accurate insight into learners' conscious thought processes. This, in turn, does not allow for any direct examination of the means by which learners change input into intake.

C. Quantitative research requires the pre-selection of variables to be observed and measured. It cannot, for instance, identify individual or psychological variables of the classroom experience. This is, as Schumann and Schumann (1977) argue, best guaranteed through qualitative research based on learners' diaries.

In brief, current classroom-process research has two major dimensions: First, it reveals previously unexplored aspects of classroom processes in which teachers and learners are engaged. The other important dimension of classroom-process research is that it may ultimately enable us to develop and test hypotheses about second language teaching and learning which reflect, better than has been done in the past, the complex activity which we seek to understand —classroom language acquisition (cf., Doyle, 1977; Freire, 1970; Lazaraton, 1994; Long, 1983; Moskowitz, 1976; Nunan, 1990).

\section{Qualitative Research}

Closely related to classroom-centered research and classroom process research is Qualitative Research (QR). Research in applied linguistics has taken on two major forms. Most traditional research projects have drawn on quantitative research methodology in which the researcher sets out to investigate already hypothesized variables. More recently a new trend in second language research methodology has come into vogue. Qualitative research has made a significant gain in terms of visibility and credibility in recent years. We should, however, admit that the purposes, assumptions, and methods of qualitative research are still debated, misunderstood, and/or ignored by some applied linguists (cf., Maxwell, 1996; Tesch, 1990).

Lazaraton (1995) draws our attention to the state of the art of research in applied linguistics. She distinguishes between the two major research methodologies of quantitative research and qualitative research. The term 'quantitative methods' is employed by Lazaraton to include the application of descriptive and/or inferential statistical procedures in research. In 
reviewing the related literature on qualitative research, Lazaraton expresses dissatisfaction in the face of the fact that there is no qualitative-research-specific text of any kind. She, however, observes that some scholars have devoted some pages of their books to a short-sighted discussion of qualitative research topics.

Nunan (1992), for instance, in Research methods in language learning states that "two alternative conceptions of the nature of research provide a point of tension within the book" (pp. xi-xii). Galguera (1993) reviews Nunan's book in Language Learning Journal, and argues that Nunan displays a bias toward his stated preference for non-experimental research despite his attempts to provide a balanced and objective view. Johnson (1992), in his book Approaches to research in second language learning, strives for balance and objectivity in the presentation of six research approaches (i.e., correlational, case study, survey, ethnography, experimental, and multisite/multimethod/large scale). Jacob (1987) notes that qualitative-quantitative dichotomy leads one to conclude that only two methodological alternatives are available to the educational researcher. In fact, Denzin and Lincoln (1994) distinguish six interpretive paradigms and perspectives that guide the research process: positivism/post positivism, constructivism, feminism, ethnic models, Marxist models, and cultural studies models.

Qualitative research has its roots in a number of traditions in different disciplines. Holistic ethnography is, for example, a qualitative research tradition that dates back to anthropology. Ethnography of communication is rooted in both anthropology and sociolinguistics. Cognitive anthropology has been widely used in both linguistics and anthropology. Other traditions include discourse analysis, phenomenology, ecological psychology, symbolic interactionism, heuristics, ethnomethodology, and hermeneutics which are rooted in linguistics, philosophy, psychology, social psychology, humanistic psychology, sociology, and theology, respectively. Hermeneutics has also been practiced in philosophy and literary criticism.

Henning (1986, p. 701) provides a definition of quantitative research as opposed to qualitative or 'anecdotal research'. Brown (1991) carefully shuns the term empirical, when discussing statistical research, stating that "there are other non-statistical studies that could be called empirical (e.g., ethnographies, case studies, etc.), since, by definition, empirical studies are those based on data (but not necessarily quantitative data)" (p. 570). 
Lazaraton (1995), in a discussion of what hinders the development of qualitative research, draws our attention to the shortcomings of qualitative research. The first problem with qualitative research is that, to date, there is no exact definition of what constitutes qualitative research. Besides the problem of definition, a fair amount of controversy exists about the scientific rigor of qualitative research. The rigor arguments seem to encompass two related issues: (1) that quantification of qualitative data is not only possible but also desirable, and (2) that quantification of qualitative data is necessary in order to make generalizable claims to and about other contexts; hence, the problem of generalizability.

Positions as to the importance of the quantification of qualitative data are two-fold. On the one hand, people like Henning (1986) take a strong position maintaining that "without some recourse to quantitative methods, some marriage of words and numbers, it is inconceivable that the investigation of language acquisition will ever be said to belong to the realm of scientific inquiry" (p. 702). Adopting a similar but somewhat weaker position, Chaudron (1988) argues that "Process-oriented qualitative researchers explore the intersubjective and context-dependent nature of classroom events as they occur, noting the regularities and idiosyncracies in the events" (p. 49).

The fact that some qualitative researchers themselves employ or recommend quantification further complicates the situation. Watson-Gegeo (1988) claims that in a hypothesis oriented mode, qualitative research may involve "quantification in the form of frequency counts, tests of significance, or multivariate analyses of patterns and themes" (pp. 584-585). All these shortcomings (i.e., lack of a precise definition, the problem of generalizability, and the tendency towards quantification) have given qualitative research the ill-state it is experiencing even today.

Perhaps the most frequent criticism leveled against qualitative research is that the results obtained through qualitative research methods are not generalizable to other contexts. In defense of qualitative research, however, Lazaraton (1995) argues that:

A. Generalizibility in research is more than a matter of counting. Quantification of any set of data does not ensure generalizability to other contexts, nor does a large sample size; population characteristics must be carefully considered when selecting a sample from which to make statistical inferences. 
B. Even meeting the most stringent criteria does not guarantee meaningful interpretation of results. Donmoyer (1990) agrees with this point and argues that "Even statistically significant findings from studies with huge, randomly selected samples cannot be applied directly to particular individuals in particular situations" (p. 181).

C. Critical theory has made a significant contribution to our profession in that we have begun to question the meaning of concepts that we had taken for granted for a long time. Matters of research methodology are not just abstract, epistemological issues about the way we view the world; they are also issues of legitimacy and power.

There are, of course, some other factors that limit the application of qualitative research methodology. According to Watson-Gegeo (1988), one reason ethnography is not more widely used in SLA studies is that it views language learning from a socialization rather than language acquisition perspective, crediting context and culture for much of what happens in the learning environment. Because many of the studies that use elicited, experimental data rarely consider these factors, it is understandable why the approach has not been more widely adopted. Second, training is another factor. Although there are books and materials available for self-study and reference, it is not an easy task to train oneself in any research methodology. Finally, anyone who has completed a qualitative research project is familiar with the sheer size of the resulting document.

\section{Quality Research}

The natural conclusion of Lazaraton's argumentation is that quantitative research is as flawed as qualitative research is. In fact, all research types have a set of cons as well as a set of pros. The choice of an appropriate research design in the language classroom will depend very much on the nature of the question to be studied in that setting. As such, and in spite of all her argumentation in favor of qualitative research, Lazaraton (1995) believes that, no matter which research methodology a researcher may draw on, he should do his utmost to do Quality Research (QLR). So, quality research can be defined as the 'optimal' research design that can be used in the language classroom. 


\section{Conclusion}

For a long time, language teachers tried to train language learners who had a near native command of the language they learnt. However, most of these efforts at training proficient learners did not bear fruit as they were expected to. Scholars attributed this failure to language teachers' confidence in language teaching methods. An 'alternative to method', rather than alternative method, was therefore what was needed in the language classroom. Hence, the era of classroom-centered research began, the aim of which was to reassign teacher plausibility to language teachers. As time passed, classroom-centered research was accompanied by a sister approach to classroom research which was called classroom process research. In addition, qualitative research also gained some reputation in this context. All of these approaches to classroom research were reviewed in this paper. The place of quality research in the language classroom context was also emphasized. 


\section{References:}

Allwright, D. (1988). Observation in the language classroom. London: Longman.

Allwright, D., \& Bailey, K. M. (1991). Focus on the classroom: An introduction to classroom research for language teachers. Cambridge: Cambridge University Press.

Allwright, R. L. (1983). Classroom-centered research on language teaching and learning: a brief historical overview. TESOL Quarterly. 17, 191-204.

Bailey, K. D. (1982). Methods of social research. New York: The Free Press.

Bailey, K. M. (1985). Classroom-centered research on language teaching and learning. In M. Celce-Murcia (Ed.). Beyond basics: issues and research in TESOL. 96-121. Rowley, MA: Newbury House.

Bailey, K. M. (1990). Diary studies in teacher education programs. In J. C. Richards and D. Nunan (Eds.). Second language teacher education. New York: Cambridge University Press.

Bartlett, L. (1990). Teacher development through reflective teaching. In J. C. Richards and D. Nunan (Eds.). Second language teacher education. New York: Cambridge University Press.

Blum, R. E. (1984). Effective schooling practices: a research synthesis. Portland, Ore.: Northwest Regional Educational Laboratory.

Brown, H. D. (1991). TESOL at twenty-five: What are the issues? TESOL Quarterly, 25(2), 245260.

Catheart, R. L., \& Olsen, J. W. B. (1976). Teachers' and students' preferences for correction of classroom conversation errors. In Fanselow and Crymes: 41-53.

Chaudron, C. (1977). A descriptive model of discourse in the corrective treatment of learners' errors. Language learning. 27, 29-46.

Chaudron, C. (1988). Second language classrooms: research on teaching and learning. Cambridge: Cambridge University Press. 
Cohen, A. (1990). Language learning: insights for learners, teachers, and researchers. New York: Newbury House.

Cohen, A., \& Hosenfeld, C. (1981). Some uses of mentalistic data in second-language research. Language Learning, 31, 285-313.

Denzin, N. K., \& Lincoln, Y. S. (Eds.). (1994). Handbook of qualitative research. Thousand Oaks, CA: Sage Publications Inc.

Donmoyer, R. (1990). Generalizability and the single-case study. In E. W. Eisner, \& A. Peshkin (Eds.), Qualitative inquiry in education: The continuing debate (pp. 175-200). New York: Teachers College Press.

Doyle, W. (1977). Paradigms of research on teacher effectiveness. In L. S. Shulman (Ed.). Review of research in education. Vol. 5. Itasca, Ill.: Peacock.

Dunkin, M., \& Biddle, B. J. (1974). The study of teaching. Washington D.C.: University Press of America.

Fanselow, J. F. (1977). The treatment of learner error in oral work. Foreign language annals. 10, 583-93.

Flanders, N. A. (1960). Interaction analysis in the classroom: a manual for observers. Ann Arbor: University of Michigan.

Flanders, N. A. (1970). Analyzing teacher behavior. Reading, MA: Addison Wesley.

Freire, P. (1970). Pedagogy of the oppressed. New York: Seabury Press.

Gaies, S. J. (1977). The nature of linguistic input in formal second language learning: Linguistic and communicative strategies in ESL teachers' classroom language. In H. D. brown, C. Yorio, \& R. Crymes (Eds.), On TESOL '77 (pp. 204-212). Washington, D.C.: TESOL.

Gaies, S. J. (1983a). The investigation of language classroom processes. TESOL Quarterly. 17, 205-17.

Gaies, S. J. (1983b). Learner feedback: an exploratory study of its role in the second language classroom. In Seliger and Long: 190-213. 
Galguera, T. (1993). [Review of the book Research methods in language learning]. Language Learning, 43, 289-294.

Gebhard, J. G., Gaitan, S., \& Oprandy, R. (1990). Beyond prescription: the student teacher as investigator. In J. C. Richards and D. Nunan (Eds.). Second language teacher education. New York: Cambridge University Press.

Hamayan, E. V., \& Tucker, G. R. (1980). Language input in the bilingual classroom and its relationship to second language achievement. TESOL Quarterly. 14 (4), 453-468.

Henning, G. (1986). Qualitative methods in language acquisition research. TESOL Quarterly, 20, 701-708.

Jacob, E. (1987). Qualitative research traditions: a review. Review of educational research. 57, $1-50$.

Johnson, D. M. (1992). Approaches to research in second language learning. New York: Longman

Krashen, S. D. (1978). The monitor model for second-language acquisition. In R. C. Gingras (Ed.), Second-language acquisition and foreign language teaching (pp. 1-26). Washington, D. C.: Center for Applied Linguistics.

Krashen, S. D. (1980). The theoretical and practical relevance of simple codes in second language acquisition. In S. D. Krashen, \& R. Scarcella (Eds.), Research in second language acquisition: Selected papers of the Los Angeles Second Language Research Forum (pp. 7-18). Rowley, Mass.: Newbury House.

Lazaraton, A. (1994). [Review of the book Approaches to research in second language learning]. TESOL Quarterly. 28, 208-209.

Lazaraton, A. (1995). Qualitative research in applied linguistics: a progress report. TESOL Quarterly. 29 (3), 455-472.

Long, M. H. (1983). Training the second language teacher as a classroom researcher. In J. E. Alatis, H. H. Stern and P. Strevens (Eds.). GURT '83: Applied linguistics and the preparation of second language teachers. Washington D.C.: Georgetown University Press. 
Long, M. H. (1980). Input, interaction, and second language acquisition. Unpublished doctoral dissertation, University of California, Los Angeles.

Long, M. H., \& Sato, C. J. (1983). Classroom foreigner talk discourse: forms and functions of teachers' questions. In Seliger and Long: 268-86.

Maxwell, J. A. (1996). Qualitative research design: An interactive approach. Thousand Oaks, CA: Sage Publications Inc.

Moskowitz, G. (1967). The FLint system: an observational tool for the foreign language classroom. In A. Simon and E. G. Boyer. Mirrors for behavior: an anthology of classroom observation instruments. Section 15, 1-15. Philadelphia: Center for the Study of Teaching at Temple University.

Moskowitz, G. (1971). Interaction analysis: A new modern language for supervisors. Foreign Language Annals, 5, 211-221.

Moskowitz, G. (1976). The classroom interaction of outstanding foreign language teachers. Foreign language annals. 9, 125-43 and 146-57.

Nunan, D. (1990). Action research in the language classroom. In J. C. Richards and D. Nunan (Eds.). Second language teacher education. New York: Cambridge University Press.

Nunan, D. (1992). Research methods in language learning. Cambridge: Cambridge University Press.

Porter, P. A., Goldstein, L. M., Leatherman, J., \& Conrad, S. (1990). An ongoing dialogue: learning logs for teacher preparation. In J. C. Richards and D. Nunan (Eds.). Second language teacher education. New York: Cambridge University Press.

Richards, J. C., \& Nunan, D. (1990). Second language teacher education. New York: Cambridge University Press.

Richards, J. C., \& Rodgers, T. S. (2001). Approaches and methods in language teaching $2^{\text {nd }}$ ed.). New York: Cambridge University Press.

Sato, C. (1981). Ethnic styles in classroom discourse. In M. Hines and W. Rutherford (Eds.). On TESOL '81. 11-24. Washington, D.C.: TESOL. 
Scherer, G. A. C., \& Wertheimer, M. (1964). A psycholinguistic experiment in foreign language teaching. New York: McGraw-Hill.

Schinke, L. (1981). English foreigner talk in content classrooms. Ph.D. dissertation, Northwestern University.

Schumann, F. E., \& Schumann, J. H. (1977). Diary of a language learner: an introspective study of second language learning. In Brown, Yorio and Crymes: 241-9.

Seliger, H. W. (1977). Does practice make perfect? A study of interaction patterns and L2 competence. Language learning. 27, 263-78.

Smith, P. D. Jr. (1970). A comparison of the Cognitive and Audiolingual approaches to foreign language instruction: The Pennsylvania Foreign Language Project. Philadelphia, Penn.: Center for Curriculum Development.

Tesch, R. (1990). Qualitative research: Analysis types and software tools. Basingstoke: Burgess Science Press.

Watson-Gegeo, K. (1988). Ethnography in ESL: Defining the essentials. TESOL Quarterly, 22, 575-592.

Mohammad Ali Salmani-Nodoushan is an assistant professor at the English Department of University of Zanjan, Iran. His research interests include language testing in general, and testing English for Specific Purposes, Computer Adaptive Testing, and Performance Assessment in particular. He is currently Head of the English Department of University of Zanjan.

Correspondence: nodushan@ut.ac.ir or nodushan@mail.znu.ac.ir

Address: English Department, College of Humanities, University of Zanjan, Iran.

Phone: 0098-241-5152664 (Office) or 0098-912-585-3505 (Cell phone) 